Chicago-Kent College of Law

Scholarly Commons @ IIT Chicago-Kent College of Law

All Faculty Scholarship

Faculty Scholarship

December 1985

\title{
Actual Causation vs. Probabilistic Linkage: The Bane of Economic Analysis
}

Richard W. Wright

IIT Chicago-Kent College of Law, rwright@kentlaw.iit.edu

Follow this and additional works at: https://scholarship.kentlaw.iit.edu/fac_schol

Part of the Law and Economics Commons, and the Torts Commons

\section{Recommended Citation}

Richard W. Wright, Actual Causation vs. Probabilistic Linkage: The Bane of Economic Analysis, 14 J. Legal Stud. 435 (1985).

Available at: https://scholarship.kentlaw.iit.edu/fac_schol/695

This Article is brought to you for free and open access by the Faculty Scholarship at Scholarly Commons @ IIT Chicago-Kent College of Law. It has been accepted for inclusion in All Faculty Scholarship by an authorized administrator of Scholarly Commons @ IIT Chicago-Kent College of Law. For more information, please contact jwenger@kentlaw.iit.edu, ebarney@kentlaw.iit.edu. 


\title{
ACTUAL CAUSATION VS. PROBABILISTIC LINKAGE: THE BANE OF ECONOMIC ANALYSIS
}

\author{
RICHARD W. WRIGHT*
}

\section{INTRODUCTION}

$\mathrm{O}$ $\mathrm{NE}$ of the focal points in the current debate about competing theories of tort liability is the actual causation requirement, which relieves a defendant of liability if his tortious conduct was not in fact a cause of the plaintiff's injury. It is generally recognized that any successful theory must come to terms with the requirement, since it has been the most pervasive and enduring requirement of tort liability over the centuries. ${ }^{1}$ But the requirement has been troublesome for modern tort theorists, because of their difficulties either in articulating its precise meaning or in fitting it into a particular theory.

The definitional problem has plagued proponents of the traditional "corrective justice" or "rights violation" theories of tort liability, which hold that, as a matter of individual justice between the plaintiff and the defendant, the defendant who has caused an injury to the plaintiff in violation of his rights in his person or property must compensate him for such injury, whether or not imposition of liability will further some collective social goal. ${ }^{2}$ The central role of the actual causation requirement in

\footnotetext{
* Associate Professor of Law, Illinois Institute of Technology, Chicago-Kent College of Law. I would like to thank my former colleagues John Hanks and Paul Shupack for their helpful comments on the initial draft of this article.

${ }^{1}$ See, for example, Oliver Wendell Holmes, Jr., The Common Law 64, 115 (Mark DeWolfe Howe ed. 1963); Leon Green, Rationale of Proximate Cause 132 (1927); H. L. A. Hart \& A. M. Honoré, Causation in the Law 59-63 (1959) (corrected printing 1967); Guido Calabresi, The Costs of Accidents: A Legal and Economic Analysis 297 (student edition 1970); Guido Calabresi, Concerning Cause and the Law of Torts: An Essay for Harry Kalven, Jr., 43 U. Chi. L. Rev. 69, at 69, 91 (1975).

${ }^{2}$ Richard A. Epstein, A Theory of Strict Liability, 2 J. Legal Stud. 151 (1973); id., Intentional Harms, 4 J. Legal Stud. 391, 441-42 (1975); George P. Fletcher, Fairness and Utility in Tort Theory, 85 Harv. L. Rev. 537 (1972).
}

[Journal of Legal Studies, vol. XIV (June 1985)]

(c) 1985 by The University of Chicago. All rights reserved. 0047-2530/85/1402-0004\$01.50 
the corrective justice theories reflects its historical importance. However, the proponents of corrective justice have failed to elaborate plausible comprehensive accounts of causation and rights. ${ }^{3}$

The corrective justice theorists have been opposed by the social welfare theorists, represented earlier in this century by the legal realists and more recently by their successors, the economic analysts. The social welfare theorists have taken the conceptual confusion surrounding the notions of causation and rights as their cue to jettison rights analysis entirely and to limit causation analysis significantly, in favor of liability based on explicit judgments of social utility or expediency. ${ }^{4}$ Indeed, the problem for the social welfare theorists has been to fit the causation requirement into their theories at all. Yet that task is essential for the positive theorists, who claim to explain the results actually reached by the courts. It is only slightly less important for the normative theorists, in view of the strong historical connection between actual causation and prevailing notions of moral and legal responsibility. ${ }^{5}$

The legal realists' version of social welfare was broad enough to encompass the actual causation requirement as a minimal justice-related condition on tort liability. ${ }^{6}$ The economic analysts, however, espouse a much narrower and more uncompromising version of social welfare that seems analytically incompatible with the actual causation requirement. This article explores that apparent incompatibility and the efforts by leading economic analysts to deal with it.

According to the economic analysts, the sole or dominant goal of tort liability is or should be the maximization of social wealth or, stated another way, the minimization of social costs. ${ }^{7}$ The mode of analysis in their

\footnotetext{
3 See Richard W. Wright, Causation in Tort Law 73 Calif. L. Rev. (1985), forthcoming; id., A Principled Theory of Toritious Conduct (in process).

${ }^{4}$ For examples from the legal realist tradition, see Green, supra note 1; Clarence Morris, Morris on Torts (1st ed. 1953); Wex S. Malone, Ruminations on Cause-in-Fact, 9 Stan. L. Rev. 60 (1956). For examples from the economic analysis perspective, see Calabresi, Concerning Cause, supra note 1; William M. Landes \& Richard A. Posner, Causation in Tort Law: An Economic Approach, 12 J. Legal Stud. 109 (1983). The economic analysts sometimes seem not to realize the extent of their intellectual debt to the legal realists. Landes and Posner assert that the legal realists were concerned only with loss spreading. William $\mathbf{M}$. Landes \& Richard A. Posner, The Positive Economic Theory of Tort Law, $15 \mathrm{Ga}$. L. Rev. 851,853 (1981). The works by Green and Morris cited above are only two of many counterexamples to this assertion. Indeed, Morris's work anticipated much of the current economic approach.

${ }^{5}$ See Hart \& Honoré, supra note 1, at 59-63; Malone, supra note 4, at 66-67; Leon Green, The Causal Relation Issue in Negligence Law, 60 Mich. L. Rev. 543, 545 (1962).

${ }^{6}$ For example, Malone, supra note 4, at 66; Green, supra note 5, at 545-46.

${ }^{7}$ Richard A. Posner, A Reply to Some Recent Criticisms of the Efficiency Theory of the Common Law, 9 Hofstra L. Rev. 775 (1981); Landes \& Posner, Positive Economic Theory,
} 
theories is forward looking, collective, and policy oriented. Injuries that have already occurred are "sunk costs" that can no longer be prevented. A defendant is held liable for a particular injury if and only if doing so will create, ex ante, incentives for the defendant or others to act more efficiently in the future or, alternatively, if the defendant is best situated to spread or absorb the loss so as to minimize the economic disruption resulting from the injury, regardless of who caused it. ${ }^{8}$

The actual causation requirement invokes a quite different mode of analysis. It is a backward-looking, individualized, and factual inquiry, which asks, ex post, after the tortious conduct of the defendant has already occurred, whether the tortious (negligent, intentional, ultrahazardous) aspect of the defendant's conduct in fact contributed to a legally redressible injury to the plaintiff. If not, there is no liability, no matter how unreasonable, dangerous, or inefficient the defendant's conduct may have been. Even if the defendant's conduct in general (for example, driving a car) contributed to the plaintiff's injuries, the defendant's liability is limited to those injuries, if any, to which the tortious aspect (for example, speeding) of his conduct contributed. ${ }^{9}$

Initially, most economic analysts tried to minimize the practical importance of the actual causation requirement. In the two seminal articles applying economic analysis to tort liability, Coase and Calabresi argued that since injuries result from the interaction of the plaintiff's and the defendant's (and others') activities, each activity is a necessary condition for-and hence a cause of - the particular interaction and its effects. Thus liability for those effects can and should be assigned among the

supra note 4. Although Calabresi nominally constrains wealth-maximization goals by justice considerations, such considerations rarely constrain his analysis. Instead, he repeatedly dismisses justice arguments as irrational pseudojustice sentiments or equates justice with maximizing wealth or shifting it to make one person wealthier than another. He seems to find it difficult to perceive any other notion of justice. Calabresi, Costs, supra note 1, at 26-33, 291-308; Guido Calabresi \& A. Douglas Melamed, Property Rules, Liability Rules, and Inalienability: One View of the Cathedral, 85 Harv. L. Rev. 1089, 1098-99 \& n.21, 1102-05 \& n.30, 1111-15 \& nn.43, 47 \& 51 (1972); Guido Calabresi, About Law and Economics: A Letter to Ronald Dworkin, 8 Hofstra L. Rev. 553 (1980); Calabresi, Concerning Cause, supra note 1, at 70-71, 91, 107-08; accord, Steven Shavell, An Analysis of Causation and the Scope of Liability in the Law of Torts, 9 J. Legal Stud. 463, 502-03 (1980); Mark F. Grady, Proximate Cause and the Law of Negligence, 69 Iowa L. Rev. 363, 372, 440 (1984).

${ }^{8}$ Richard A. Posner, Economic Analysis of Law 18 (2d ed. 1977); Calabresi, Costs, supra note 1 , at 26-28, $201 \&$ n.2, 203.

${ }^{9}$ Restatement (Second) of Torts $\S 432$ (1965); Restatement of Torts $\S 519$ (1938); Charles E. Carpenter, Workable Rules for Determining Proximate Cause (pt. II), 20 Calif. L. Rev. 396, 408-19 (1932); Hart \& Honoré, supra note 1, at 111-12, 191-92, 237-38; Robert E. Keeton, Legal Cause in the Law of Torts 4-9, 12-13 (1963); Richard A. Posner, A Theory of Negligence, 1 J. Legal Stud. 29, 40 (1972). 
interacting activities in the way that will maximize social wealth. ${ }^{10}$ That is, the actual causation requirement is trivially satisfied by each of the interacting activities and is of no use in assigning liability, which is governed by the wealth-maximization criterion.

But this response merely skips over the actual causation requirement. It does not explain or justify the existence of the requirement or its prominent position in tort law over the centuries. It does not explain why, in accordance with the requirement, liability is limited to those situations in which an injury has occurred and is further limited to harm that was caused by the tortious aspect of the defendant's activity. Since economic analysis is concerned solely with ex ante incentives for efficient (wealthmaximizing) behavior, not with ex post compensation of injuries, it would seem that liability equal to the expected harm should be imposed on the defendant whenever he behaves inefficiently, whether or not an injury occurs or-to reduce enforcement costs-at least whenever his behavior contributes to an injury, whether or not the injury was caused by the inefficient aspect of his behavior. ${ }^{11}$

When Calabresi turned to these and related issues in his normative analysis of accident law, he seriously questioned both the efficiency and the intelligibility of the causation requirement. He argued that fines should be assessed against clearly inefficient activities, whether or not an injury occurs, and that even if a particular category of activities is efficient, it should be held liable for injuries for which it is the "cheapest cost avoider," whether or not it was an actual cause of the injuries. ${ }^{12}$

Within a few years, however, Calabresi's hostility to the causation requirement wavered. In 1975 , explicitly recognizing the historical persistence and normative pull of causation concepts, he presented a positive economic theory of causal analysis in tort law. ${ }^{13}$ His article prompted Shavell, writing in 1980, and Landes and Posner, writing together in 1983, to address the problem also. ${ }^{14}$

10 R. H. Coase, The Problem of Social Cost, 3 J. Law \& Econ. 1, 2, 13, 19, 27 (1960); Guido Calabresi, Some Thoughts on Risk Distribution and the Law of Torts, 70 Yale L. J. 499, 505-06 \& n.24 (1961).

11 In order to emphasize the causation issues, I assume for purposes of argument in this article that tortious behavior is equivalent to inefficient behavior, or at least behavior by the cheapest cost avoider, as Posner has often claimed. See, for example, Posner, supra note 9 , and Landes \& Posner, Positive Economic Theory, supra note 4. I do not believe this alleged equivalence actually exists, nor does Calabresi. See Calabresi, Costs, supra note 1, at 24163; Calabresi, Concerning Cause, supra note 1, at 82-83 \& n.19.

12 Calabresi, Costs, supra note 1, at 6-7 n.8, 22-23, 150, 156, 239-43, 247-51, 254-57, 266-70, 272, 274-76, 278, 286-87, 303-04.

13 Calabresi, Concerning Cause, supra note 1.

14 Shavell, supra note 7; Landes \& Posner, Causation, supra note 4. 
In this paper, I demonstrate that the efforts of these economic analysts to reconcile the actual causation requirement with their wealthmaximization theories all contain analytical errors. Once these errors are corrected their arguments backfire: they not only fail to explain the existence and prominence of the actual causation requirement, but also make it increasingly clear that the requirement is-as first suggested by Calabresi-incompatible with wealth maximization. As we shall see, a major source of these errors is the analysts' frequent confusion of actual causation of injury with increased risk of injury. The latter corresponds to what Calabresi calls "causal linkage" and Shavell calls "probabilistic cause." 15 In the interests of semantic accuracy and clarity of exposition, I shall use the terms "increased risk," "expected harm," or "probabilistic linkage," as appropriate.

\section{Calabresi}

Calabresi's 1975 article on causation is devoted to answering the following positivist question: "[W]hat role does causal language play in the achievement of certain [wealth-maximization] goals that have come to be accepted as crucial to the law of torts?",16

Calabresi identifies three different "causal" concepts. The first"causal linkage" - is not really a causal concept but is rather a novel term for a forward-looking concept of increased risk more accurately referred to as "probabilistic linkage." A specific act is probabilistically linked to a specific injury, whether or not it contributed to the injury, if we believe that recurrence of the act in the future will increase the risk of occurrence of a similar injury. ${ }^{17}$ The second concept is the familiar "but-for" (necessary condition) test of contribution to the specific injury, which works well as a test of actual causation except in certain infrequent cases of overdetermined or doubtful causation. ${ }^{18}$ The third concept- " proximate causation" - is also familiar. It subsumes or presupposes the actual cau-

\footnotetext{
15 Calabresi, Concerning Cause, supra note 1, at 71-72; Shavell, supra note 7, at 468 \& n. 17 .

16 Calabresi, Concerning Cause, supra note 1 , at 71.

${ }^{17}$ Id. at 71-72. It is not clear if the concept is limited to situations in which a specific injury has occurred, or is applied more broadly to refer simply to increased risk. See $i d$. at $71-72,73-74,78,84-85$. Hart and Honoré, whose work Calabresi cites as especially significant in the development of his ideas, had previously mentioned and critiqued a probabilistic linkage concept of causal responsibility. Hart \& Honoré, supra note 1, at 45-46, 269 70, 411-39, cited in Calabresi, Concerning Cause, at $69 \mathrm{n.1}$; see Shavell, supra note 7, at 468 n.17.

${ }^{18}$ Calabresi, Concerning Cause, supra note 1, at 72, 86-87 \& n.23; see Calabresi, Costs, supra note 1, at 275 n.1.
} 
sation requirement but, in the words of Prosser, invokes "more or less undefined [policy] considerations" to limit liability further "even where the fact of causation is clearly established." 19 Insofar as the term proximate causation is used, as by Calabresi, to refer to these additional policy limitations, it also (like probabilistic linkage) is not a causal concept.

These three concepts are measured against Calabresi's wealthmaximization "goals," which are actually techniques for achieving the basic objective of minimizing the total social costs of accidents. The "goals" are (1) "collective deterrence"' (by prohibition) of specific activities deemed to be inefficient; (2) "market deterrence" of non-costminimizing behavior in general, through allocation of injury costs to the activity deemed to be the "cheapest cost avoider" with respect to such injury costs; and (3) minimization of secondary (loss bearing) costs through allocation of injury costs to the activity which can best (a) "spread" those costs throughout the economy or $(b)$ absorb them itself by virtue of its "deeper pockets." 20

As Calabresi himself demonstrates, neither the actual causation requirement (represented by the but-for test) nor the pseudocausal concepts of probabilistic linkage and proximity are explainable in terms of the lossspreading or deep pocket goals. There is no necessary, or even approximate, connection between the party who has caused the loss and the party who is best able to spread or absorb it once it has occurred. Nor does the belief that certain activities increase the risk of (are probabilistically linked to) future injuries have anything to do with their ability to spread or absorb the losses that have already occurred. (He admits that it would be relevant to their ability to spread future losses, but states that this "has nothing to do with causation as it has been used in tort law." $)^{21}$ Similarly, although some elements of proximity analysis, such as the foreseeability of the injury and the size of the damages, are relevant to the ability to spread or absorb losses, their usefulness is severely limited by their status as supplements to the actual causation requirement. ${ }^{22}$

Calabresi also admits that the actual causation requirement is inconsistent with the collective deterrence goal. If an activity is thought to be socially inappropriate because of excessive risk (a determination that necessarily includes a finding of probabilistic linkage to future injury), it should ideally be penalized whenever it occurs, whether or not it was an

19 William L. Prosser, Handbook of the Law of Torts 244 (4th ed. 1971); see Calabresi, Concerning Cause, supra note 1 , at 72, 74-76.

${ }^{20}$ Id. at 73, 77-78, 84; see Calabresi, Costs, supra note 1, at 26-28, 39-75, 135-97.

21 Calabresi, Concerning Cause, supra note 1, at 74.

22 Id. at 73-77. 
actual cause of any harm. ${ }^{23}$ This goal is reflected in the criminal law, which punishes attempts as well as successful crimes. ${ }^{24}$ Even if it is too costly to detect and fine every instance of the collectively proscribed behavior, so that, for example, punishment is limited to instances in which an accident occurs, there would be no reason to require that the proscribed behavior have been a cause of the injury (if any) or even of the accident, or to measure the penalty by the damages (if any) that were caused by the proscribed (tortious) aspect of the defendant's behavior. Yet all of these limitations are imposed by the actual causation requirement. $^{25}$

The only use Calabresi can find for the actual causation requirement in furthering market deterrence is simply as one of several alternative methods for creating "an actuarial basis from which actors can decide whether future safety costs are cheaper or more expensive than future injury costs." 26 The actual causation requirement allegedly ensures that statistics on past injury costs reflect those and only those injury costs affected by past decisions on the levels of activity and care.

As Calabresi notes, however, the case-by-case application of the actual causation requirement in tort adjudication is not the only, let alone the best, way to create such an actuarial data base. A more accurate and far less expensive alternative might well be a tort fine or tax based on random sampling of past injuries associated with the activity. The sampling method would probably utilize fewer incidents, would not be biased toward those accidents that reach the courts, and would reduce participants' incentives to give inaccurate descriptions of accidents. ${ }^{27}$

Moreover, the assumptions underlying the alleged actuarial utility of any actual causation requirement are very tenuous. At a minimum, it must be assumed that actors have access to the relevant data base (if one exists), that they are able to interpret the data in a correct fashion, and that they will act efficiently given the interpretations so reached. But why make these assumptions? Even access to insurance information is not sufficient to discharge these functions, as it is commonplace that insurance coverage often lumps together different risks in working its conversion from expected risks to the prepaid insurance premium. ${ }^{28}$

${ }^{23}$ Id . at $78-79$.

24 Rollin M. Perkins, Criminal Law 552-77 (2d ed. 1969).

${ }^{25}$ Calabresi, Concerning Cause, supra note 1, at 79; Calabresi, Costs, supra note 1, at 269-70 \& n.5.

26 Calabresi, Concerning Cause, supra note 1 , at 85.

27 Id. at 85-86; Calabresi, Costs, supra note 1, at 251 \& n.8, 257-58, 287 n.2.

${ }^{28}$ Id. at $247-49$. 
Most important, the damages assessed under the actual causation requirement do not include all the losses caused by an activity, and so the damage statistics do not provide a basis for the complete comparison of future safety and injury costs needed to determine the efficient levels of activity and safety. This is so for two reasons. First, damages are awarded only for injuries caused by the tortious (for example, negligent) aspect of a defendant's activity, rather than for all injuries caused by the activity. Second, even injuries caused by the tortious aspect of the defendant's activity are unlikely to be fully included, because of the costs of litigation, proof problems, market valuation of losses, and limitations on the type and extent of recoverable losses. ${ }^{29}$

Even if the actual causation requirement had the limited, substitutable use Calabresi claims for it in relation to market deterrence, that single minor and incidental connection to his wealth-maximization goals would hardly account for its universal pervasiveness, as Calabresi recognizes. Therefore, at the end of his article, he renews his attacks on the traditional backward-looking, contribution-to-the-injury meaning of the requirement. He attempts to recast the requirement as a "flexible and functional" term that does not refer to any "inherent, "natural' relationships", but that, because of its "historical, common law gloss" and moral appeal, can and should be used to camouflage the process of "identify[ing] those pressure points that are most amenable to the social goals we wish to accomplish." 30

Calabresi's unsuccessful effort to reconcile the actual causation requirement with wealth-maximization goals illustrates a major source of difficulty for wealth-maximization theories: the inconsistency of their forward-looking focus with the backward-looking elements of tort liability. The actual causation requirement is the major, best-known example of such an element, but the difficulty extends further than is usually realized. This point can be illustrated by a brief consideration of one of the principal elements of proximate causation analysis: the past foreseeability limitation, which is frequently invoked to restrict liability to risks that were actually foreseeable beforehand in the particular case by a person in the defendant's position. ${ }^{31}$

Initially, Calabresi recognizes that, whether or not the risk that materialized was foreseeable beforehand in the particular case, imposition of

\footnotetext{
29 See, for example, W. Kip Viscusi, Alternative Approaches to Valuing the Health Impacts of Accidents: Liability Law and Prospective Evaluations, 46 Law \& Contemp. Probs. 49 (1983).

30 Calabresi, Concerning Cause, supra note 1, at 106-8.

${ }^{31}$ See Prosser, supra note 19 , at 250-88.
} 
liability sends the desired signal to persons contemplating similar activities in the future. ${ }^{32}$ But he seems to neglect the effect on future incentives when discussing collective deterrence, where he argues that it is useless to penalize "actors who neither knew nor should have known of [the] risk before the accident" because "[s]uch penalties cannot alter dangerous behavior.",33

Perhaps Calabresi meant that imposing liability when past foreseeability is lacking would add nothing useful to the signal sent to future actors by imposing liability when past foreseeability exists. But this argument, which is suggested by his treatment of market deterrence ${ }^{34}$ is not persuasive. Even if, as assumed, the ex ante incentive to minimize future costs is no greater without the limitation, it also is no less, and extensive administrative costs are required to distinguish instances of past foreseeability from instances of past unforeseeability. Moreover, the ex ante incentive to minimize costs will be greater without the limitation, since actors will have a greater incentive to discover previously unknown risks and to act on privately held information that they might be able to shield from discovery after the fact. In contrast, with the limitation, the incentive is to avoid investigating or acting on risks until they become publicly known.

Calabresi also discusses the cases where the defendant has failed to exercise reasonable care in the light of the foreseeable risks, only to cause an unforeseeable injury. The classic case is Palsgraf $v$. Long Island $R . R .{ }^{35}$ in which Mrs. Palsgraf was injured when railroad employees negligently helping a passenger onto a moving train caused him to drop a package containing concealed fireworks, which exploded and caused scales on the other side of the platform to fall on Mrs. Palsgraf. As Calabresi acknowledges, the fact that a particular injury was unforeseeable to the defendant beforehand does not mean that it was any more foreseeable to the plaintiff, or that the plaintiff was in a better position to act to avoid the injury. ${ }^{36}$ Indeed, since the unforeseen injury could have been avoided by the defendant by simply exercising the care that was called for in the light of the foreseeable risks, the extra safety cost required to avoid the unforeseeable injury is zero. This not only makes the

32 Calabresi, Concerning Cause, supra note 1 , at $87-88$.

33 Id. at 81 .

${ }^{34}$ Id. at 88; accord, Grady, supra note 7 , at 440,449 . Calabresi's exception for activities especially prone to unforeseeable risks is not an exception. There is a foreseeable increased risk of harm from engaging in such activities even though the precise risks are not foreseeable.

35248 N.Y. 339, 162 N.E. 99 (1928).

36 Calabresi, Concerning Cause, supra note 1, at 93-96, 99-100. 
past foreseeability limitation in these types of cases "not comprehensible in terms of collective deterrence," as Calabresi states, ${ }^{37}$ but also incomprehensible in terms of market deterrence. Both Calabresi and Posner miss this point because they analyze these cases using an ex post focus on the past foreseeability of the particular injury that occurred, rather than an ex ante focus on who is the cheapest cost avoider of future (foreseeable and unforeseeable) injury. ${ }^{38}$

\section{Shavell}

Shavell explicitly adopts Calabresi's instrumental approach of evaluating "causal" limitations on tort liability in terms of their usefulness in furthering postulated wealth-maximization goals, although Shavell-like most other economic analysts-focuses on deterrence effects and administrative costs and does not consider cost reductions achievable through loss spreading or shifting. ${ }^{39}$ Shavell also follows Calabresi by equating actual causation with the but-for test and by describing the probabilistic linkage concept, which he calls "probabilistic cause" rather than "causal linkage," as an alternative "basic notion of causation." 40

But the similarity ends there. Calabresi claims only limited, indirect, and substitutable use for the actual causation requirement and has difficulty explaining the past foreseeability limitations except as manipulable argumentative devices. Shavell, on the other hand, claims to prove that the actual causation requirement, the past foreseeability limitations, and other "causal" limitations are required by wealth-maximization policy: "[G]iven the assumptions of the [wealth-maximization] model, it will be deduced that the principles of causation in fact, of harm occurring within the normal risk created by an act, etc. implicitly serve to maximize social welfare [wealth] and thus ought to be employed to limit the scope of liability." 41

As we shall see, Shavell's proof relies on unrealistic assumptions, contrived illustrations, and faulty mathematical formulas. But the basic flaw in his exposition is a confusion of forward-looking risk analysis with backward-looking causal and foreseeability analysis.

Shavell begins with the economic analyst's usual list of unrealistic as-

37 Id. at 94 .

38 Id. at 92, 100; Posner, supra note 8, at 130, and supra note 9, at 42; compare Landes \& Posner, Causation, supra note 4, at 128, 130.

39 Shavell, supra note 7, at 464-65.

40 Id. at 466-69 \& n. 17.

41 Id. at $465-66$. 
sumptions and adds a few more, including the following: (1) the victim is completely passive (his behavior has no influence on accident losses); (2) injurers have perfect ex ante knowledge about the magnitude and probability of all losses that may occur; (3) courts have perfect knowledge about each accident (including the ex ante expected losses); (4) courts are often unable to identify the increment in accident losses caused by the injurer's activity; and (5) administrative costs occur only for accidents within the scope of liability. ${ }^{42}$

Burrows has discussed in detail the logical inconsistency of Shavell's assumptions 3 and 4, Shavell's practice of dropping or reversing assumptions where necessary to advance his argument, and the devastating effect that these inconsistencies and reversals have on Shavell's argument as a whole. ${ }^{43}$ But even if these inconsistencies and reversals are ignored, Shavell's argument fails to accomplish the advertised reconciliation of causal analysis and wealth-maximization analysis.

Shavell's deduction of the actual causation requirement is based on several of his contrived numerical examples and an alleged mathematical proof in an appendix, all of which assume a rule of strict liability. The nature of and defects in his argument can be illustrated by his bicyclistjogger example.

In the example, a jogger in a park will inevitably suffer an ankle sprain if visibility is poor. If the bicyclist is not also in the park, the jogger will trip on a fallen branch. If the bicyclist is in the park, he will run into the jogger just as the jogger is about to trip, whether or not the bicyclist is careful, and the jogger will suffer exactly the same ankle sprain. Otherwise, the jogger will be injured only if visibility is moderate and the bicyclist is riding carelessly in the park. The bicyclist never knows whether visibility is poor, moderate, or good, but he does know before deciding whether to enter the park or to ride carefully the exact probabilities that the visibility will be poor, moderate, or good and the exact losses that will occur if he rides carelessly or carefully or stays away from the park, given each possible state of visibility.

Shavell picks the visibility probabilities and loss magnitudes so that the "first-best" (social-wealth-maximizing) solution is for the bicyclist to enter the park and ride carefully, but the (almost) omniscient bicyclist will decide not to enter the park because his expected liability is too high-a result Shavell characterizes as "crushing liability." But, again given the

\footnotetext{
${ }^{42}$ Id. at 471-72, 476 n.35, 485-86, 490 n.46.

43 Paul Burrows, Tort and Tautology: The Logic of Restricting the Scope of Liability, 13 J. Legal Stud. 399 (1984).
} 
carefully chosen numbers, the bicyclist will adopt the first-best solution if there is no liability when visibility is poor, which happens to be the visibility state in which his bicycle riding is not a but-for cause of the jogger's injury. Thus the but-for test is necessary for wealth maximization. ${ }^{44}$

There are numerous problems with this crushing liability argument.

First, it should be apparent that the argument does not employ the ex post, backward-looking inquiry into what actually happened, irrespective of what was foreseen or known beforehand, which is the essence of the actual causation inquiry. Instead, Shavell describes a situation in which, ex ante, the bicyclist deciding whether to enter the park or ride carefully knows his decision will not increase the risk of (is not probabilistically linked to) poor visibility losses. The argument as presented is a forwardlooking risk analysis argument, not a backward-looking actual causation argument. The same erroneous identification of lack of probabilistic linkage with the actual causation limitation occurs in (and invalidates) Shavell's mathematical "proof." 45

Second, and related to the first point, the example does not portray a situation in which actual causation is lacking when visibility is poor. True, the but-for test is not satisfied, but this is one of those infrequent situations in which the but-for test is generally recognized as an inadequate test of actual causation. If the bicyclist enters the park, "he will run into the jogger when [the jogger] is about to trip on the branch" 46 and suffer the same injury. The fact is that the first factor-the bicyclist's running into the jogger-is the one that actually occurs and causes the injury; the second factor-the jogger's tripping on the branch-would have been a cause if it had occurred first or simultaneously, but in fact it never even occurs. The situation is an example of preemptive causation, ${ }^{47}$ in which the courts usually have no problem identifying defendants such as the bicyclist as causes of the injuries, although in some cases they may limit liability for noncausal policy reasons if the preempted factor was not a legally responsible one (for example, if it was an "act of God"). ${ }^{48}$

Third, at best, Shavell's argument can be rephrased as an assertion that future accidents contributed to (caused) by an activity, but which would have occurred anyway as a result of other factors that were present,

\footnotetext{
44 Shavell, supra note 7, at 472-73 (example 3), 477-78 (example 6).

45 Id. at 509.

${ }^{46}$ Id. at $472-73$ (emphasis added).

47 See Wright, Causation in Tort Law, supra note 3.

48 Id.; Hart \& Honoré, supra note 1, at 219-29; Green, supra note 1, at 168-70.
} 
should not be charged to that activity if the ex ante expectation of liability for such causally overdetermined accidents would lead people not to engage in the activity, even though they otherwise would have done so and it is socially desirable for them to do so. (This is how Landes and Posner rephrase Shavell's argument.) ${ }^{49}$ But such instances of causally overdetermined accidents must be cases of either preemptive or duplicative causation-that is, cases in which another factor, in addition to the activity, would have been sufficient (preemption) or actually was sufficient (duplication) for the occurrence of the accident. The rarity of such cases makes it extremely unlikely that they would be foreseen or, if foreseen, would affect the decision of anyone who contemplated engaging in the activity. Moreover, we have already noted in point two above that the courts have imposed liability in the preemptive causation cases, and we will see in point five below that they have also imposed liability in the duplicative causation cases. Thus, from both the normative and positive perspectives, Shavell's argument fails.

Fourth, when the poor visibility losses are excluded from the scope of the bicyclist's liability to avoid a possible crushing burden on the bicyclist, they do not disappear. They fall on the jogger, where they likewise may be crushing. That is, he may decide to forgo jogging in the park to avoid the expected losses resulting from being hit by the bicyclist when visibility is poor, even though total wealth would be maximized if he jogged in the park. Shavell (and Landes and Posner) can avoid this dilemma only by invoking the unrealistic assumption that victims are "passive" - that is, that changes in their behavior to avoid loss will not be undertaken because they are too costly $y^{50}$ or, if undertaken, will not avoid the loss. ${ }^{51}$

Fifth, as Shavell recognizes, the courts have not adhered to the but-for limitation in the duplicative causation cases, in which the independent act of each of two injurers contributes to, and is sufficient by itself for the occurrence of, the victim's injury. Shavell asserts that neither injurer's activity is an actual cause of the injury in such cases, since neither passes the but-for test given the existence of the other, and he claims to prove mathematically that wealth is maximized by adhering to the but-for test if

49 Landes \& Posner, Causation, supra note 4, at 117-18.

so Id.

s1 Shavell, supra note 7, at 471. Shavell later claims that there will be no effect on victims' behavior even when the passive victim assumption is dropped. But he erroneously assumes that any injury included within the scope of the injurer's liability will also be included within the victim's. Id. at 496 . He apparently has forgotten his own earlier proof that in these "bilateral" accident cases, there is no first-best solution. Steven Shavell, Strict Liability versus Negligence, 9 J. Legal Stud. 1, 6-7 (1980). 
the two activities are truly independent. ${ }^{52}$ The courts and laymen, of course, have little difficulty perceiving that each of the two activities contributed to (was a cause of) the injury, although neither was a but-for cause, and liability is imposed on each injurer. ${ }^{53}$ Shavell explains such liability as necessary to deter injurers from acting in concert in order to escape liability under the but-for test, but he admits that the courts have not limited liability to such instances of proven or possible collusion. ${ }^{54}$ In fact, they have stressed the importance of compensating innocent injured parties who were negligently exposed to the risk that materialized.

Sixth, Shavell also fails to explain the results in the so-called alternative causation cases, in which it is known that one (but only one) of the defendants was a cause of the injury to the victim, but there is no way to tell which one it was. For example, two hunters independently fire their shotguns in the victim's direction, and a single (untraceable) pellet strikes the victim. The courts in such cases have not required the victim to establish which defendant was the actual cause of the injury, but have held each negligent defendant liable unless he proves that he was not the cause. ${ }^{55}$ In his discussion of these alternative causation cases, unlike his treatment of the preemptive and duplicative causation cases, Shavell recognizes that withholding liability theoretically (but not practically) ${ }^{56}$ weakens the incentive of the injurers to avoid inflicting the real losses that occur in such cases, ${ }^{57}$ but his mathematical proof that each hunter should be strictly liable is flawed.

Shavell's proof assumes that the ex ante probability of both hunters' hitting the victim is zero. This means that $P_{1}$ times $P_{2}$ equals zero, since the probability that two independent events will both occur is the product of the separate probabilities that each will occur. But if $P_{1}$ times $P_{2}$ equals zero, either $P_{1}$ or $P_{2}$ has to be zero, and in fact both must be zero since Shavell also assumes $P_{1}$ equals $P_{2}$. Shavell's simplifying assumptions reflect a situation in which there is no ex ante chance of either hunter's shooting the victim. He has once more confused ex ante probabilities with

\footnotetext{
52 Shavell, supra note 7, at 494-95 \& n.57. In his derivation of the first-best solution, he assumes that the injurers' activities are independent (neither influences the other), but then he has each injurer using knowledge of the other's optimal level of care to select his own optimal level of care, a procedure which seems both circular and contrary to the independence assumption.

53 For example, Corey v. Havener, 182 Mass. 250, 65 N.E. 69 (1902); see Hart \& Honoré, supra note 1 , at 216-19, 224-25.

54 Shavell, supra note 7 , at $495 \&$ n.57.

55 Summers v. Tice, 33 Cal. 2d 80, 199 P.2d 1 (1948).

56 See point three at 446-47 supra.

57 Shavell, supra note 7, at 494.
} 
ex post factual determinations of what actually happened. Ex post, we know that only one pellet actually struck the victim, but ex ante there was a chance (however small) that both hunters might hit the victim, since they each shot in his direction. ${ }^{58}$

Shavell's only other argument for restricting the scope of strict liability relies on alleged savings in administrative costs. For Shavell, administrative costs are "wasted" if they are spent on compensation for injuries that do not need to be included within the scope of liability in order to maintain a sufficient incentive for the injurer to make the proper (wealthmaximizing) decision on whether to engage in an activity or to exercise care. Shavell would include only the minimum number of accident types within the scope of liability that is barely sufficient to induce the injurer to adopt the desired wealth-maximizing behavior. ${ }^{59}$

The courts, of course, do not restrict the scope of liability in this fashion. Apart from fairness considerations, the courts do not have the assumed perfect knowledge of the probability and magnitude of all possible losses required to implement this approach. Even if they did, restricting the injurer's scope of liability in such a wholesale way would greatly increase the danger of leaving a crushing burden on the victim.

At best, the approach could be applied to the infrequent causally overdetermined accidents or the slightly more frequent unforeseeable accidents, as suggested subsequently by Landes and Posner. ${ }^{60}$ But, as we have already seen, the courts impose liability in the causally overdetermined (preemptive and duplicative causation) cases, and they also often impose liability in the unforeseeable accident cases. ${ }^{61}$ That is, the argument, even if valid economically, ${ }^{62}$ is not followed by the courts and thus fails as a positivist explanation of their behavior.

When Shavell turns from strict liability to negligence, he asserts that the situation is radically different in theory but the same in practice. More

58 Id. at $\mathrm{n}$. 56. The same confusion appears in his discussion of the appropriate scope of the defense of contributory negligence in the Smithwick case, when he assumes that there was zero ex ante probability that the victim would both slip on the platform and be hit by the collapsing wall. Id. at 496 \& n.61, discussing Smithwick v. Hall \& Upson Co., 59 Conn. 261, 21 A. 924 (1890).

59 Shavell, supra note 7, at 480-81, 484.

60 Landes \& Posner, Causation, supra note 4, at 116-17, 121, 125-33.

${ }^{61}$ For example, Petition of Kinsman Transit Co., 338 F.2d 708, 723-25 (2d Cir. 1964); see Green, supra note 1, at 177-80; Hart \& Honoré, supra note 1, at 45-46, 77, 140-41, 164-65, 184-85, 230-60, 268-70, 411-39; Prosser, supra note 19, at 250-88; Jeremiah Smith, Legal Cause in Actions of Tort, 25 Harv. L. Rev. 103, 105, 114-28, 223-52, 303-7 (1911-12).

${ }^{62}$ See Burrows, supra note 43 , at $409-10$ for a critique of the assumption that scope limitations reduce total administrative costs. See also discussion at 443 supra of the adverse incentive effects of the foreseeability limitation. 
specifically, he argues that the actual causation requirement works against wealth maximization under an ideal negligence system, but that in practice the negligence system contains a "significant element" of strict liability and therefore the actual causation requirement is needed.

Under the ideal negligence system, Shavell notes, the injurer's crushing liability problem disappears. In fact, precisely the opposite problem occurs. As long as the injurer is operating at the prescribed due-care level, he is not liable for any losses caused by his activity. Therefore, there is no danger that he might forgo a socially worthwhile activity or inefficiently reduce the level of the activity because of expected liability that exists even though he is exercising the efficient level of care: there is no such expected liability. The danger is rather that, since he is immunized from liability when he exercises the efficient level of care, he may engage in an activity or increase the level of the activity even when it is not socially desirable for him to do so. For example, he may drive carefully around an unfenced playground continuously every hour it is open every day of the year, for no purpose other than the pleasure of driving or playgroundcircling.

Restricting the scope of liability through the actual causation limitation or any other limitation on damages will only exacerbate this problem, and it will also reduce the actor's incentive to exercise the efficient level of care. He, of course, will never have any reason to exercise more than due care, no matter how great the expected liability when he is below the duecare level, since liability cuts off as soon as he reaches the due-care level. Thus, from the standpoint of incentives to engage in the efficient levels of activity and care, there is not only no reason to restrict the scope of liability but also very good reason not to restrict it under the negligence liability rule. ${ }^{63}$

Nevertheless, Shavell would restrict the scope of liability if the adverse effects on the incentives to behave efficiently were outweighed by savings in expected administrative costs (due to fewer cases being adjudicated). The administrative cost argument is similar to the one he made under the strict liability rule and is subject to the same objections. But there is one very important difference. Under each rule, the accident types to be excluded from the scope of liability are those which have the least effect on the incentives to exercise the efficient levels of activity and care. Under the strict liability rule, the most obvious candidates are the accident types least affected by the level of activity or care: those that fail the but-for test. But under the negligence rule, the most obvious candidates are the accident types with the smallest expected losses, whether or not

63 Shavell, supra note 7 , at 486. 
they fail the but-for test. Thus Shavell finds no basis for the actual (butfor) causation requirement under the negligence liability rule. ${ }^{64}$

Shavell has made a very persuasive argument for the incompatibility of the actual causation requirement with wealth maximization under the negligence liability rule, which of course is not what he really wants to do. He attempts to extricate himself from this dilemma with the following three sentences:

In reality a significant element of strict liability is inherent in the negligence rule: injurers who do in fact act with due care or attempt to do so will sometimes be found negligent and have to pay damages. Courts might make mistakes in formulating due care standards or in gathering facts; injurers might err in deciding how much care to exercise; and an often probabilistic relationship exists between the care injurers generally endeavor to exercise and their momentary behavior. Introducing such possibilities into our model would have made all the conclusions reached about the scope of liability under strict liability relevant under the negligence rule. ${ }^{65}$

Even if these considerations were sufficient to convert Shavell's negligence system into his strict liability system, I have demonstrated above that Shavell's arguments for the actual causation requirement under a rule of strict liability contain many errors and generally reach results contrary to those of the courts.

In addition, the practical considerations mentioned by Shavell do not make the situation under his negligence system economically equivalent to the situation under his strict liability system. Injurers are as likely to be mistakenly over the due-care level as to be under it. Similarly, the courts are as likely to underestimate due-care standards as to overestimate them. Overall, therefore, an actor might still minimize the sum of his accident prevention costs and expected liability costs by trying to adhere to his best estimate of the due-care level.

At most, if there is no actual causation limitation on the damages an injurer must pay if he is negligent, he might have an incentive to exercise a little extra care to make sure he will not be found negligent; rarely will he decide not to engage in the activity at all, which is the problem under strict liability. But, with the actual causation limitation, as Shavell has demonstrated, the injurer will have an incentive to exercise insufficient care and an increased incentive to overengage in the activity. Either way, the situation is different from the one under strict liability. And the incentives created by the negligence system with the actual causation require-

64 Id. at $487-89$.

${ }^{65}$ Id. at 489. 
ment seem worse than those created by the negligence system without the actual causation requirement. ${ }^{66}$

\section{Landes And Posner}

Landes and Posner, who have been the most prolific and insistent positive economic analysts of tort liability, did not systematically address the actual causation requirement and its applications until, encouraged by the efforts of Calabresi and Shavell, they finally confronted these issues in an article published in 1983 .

Although they draw heavily on Shavell's analysis, their basic position is more akin to Calabresi's, but also more radical. Whereas Shavell attempted to validate the use of the traditional causal limitations by demonstrating that they are necessary parts of the wealth-maximization analysis, Landes and Posner attempt to demonstrate that the causal limitations can be entirely dispensed with. They argue that the results in all the various types of causation cases-indeed, in every tort case-can be explained completely by the use of Judge Learned Hand's formula, which defines negligence as inefficient behavior, and that there is no reason for the economic analyst to use the actual causation requirement or any other "causal" concept other than the probabilistic linkage concept already embodied in the Hand formula. ${ }^{67}$

Almost immediately, Landes and Posner implicitly backtrack on their assertion that the Hand formula can be used to decide tort questions generally. They admit that its only use in the context of strict liability is to examine the level of care that will be undertaken by the injurer, ${ }^{68}$ which is

66 This assertion is strengthened and argued in detail in Richard W. Wright, The Failure of the Positive Economic Theories of Negligence (January 1985) (unpublished paper, Ill. Inst . Tech., Chi.[-]Kent College of Law).

67 Landes \& Posner, Causation, supra note 4, at 110-11. Landes and Posner's modification of the Hand formula introduces fixed standards of care that may or may not be efficient and that are the starting point for the Hand formula analysis, contrary to all their earlier writings, which were devoted to the thesis that standards of care are efficient and are the end result of the Hand formula analysis. Id. at 112; compare Posner, supra note 9; Landes \& Posner, Positive Economic Theory, supra note 4. They also introduce two independent types of injurer care ( $y$ and $z$ ) in order to develop their modified formula. The $z$-care affects the probability that the applicable standard will be violated, but purportedly does not affect the probabilities that an accident will occur given either violation or nonviolation of the standard, which rather depend on the $y$-care. Similarly, the $y$-care purportedly does not affect the probability that the applicable standard will be violated. Landes \& Posner, Causation, supra note 4, at 111-14 \& n.12. But, contrary to Landes and Posner's model, the probability that an accident will occur often depends on the extent to which the injurer's $z$ care is above or below the standard-for example, the extent to which the injurer's speed is above or below the speed limit standard. Moreover, in their applications of their modified formula, Landes and Posner rarely illustrate two distinct types of injurer care.

68 Landes \& Posner, Causation, supra note 4, at 114-15. 
not an issue in strict liability cases. The formula cannot explain why liability is imposed in strict liability cases even though the injurer exercised the efficient level of care.

Of more direct interest, however, is their claim that the Hand formula analysis can explain the results in the various types of causation cases, without using causal analysis. As we shall see, they duplicate Shavell's error of confusing ex ante probabilistic linkage (increased risk) analysis with ex post actual causation analysis, but to a different effect. Shavell uses ex ante risk analysis and claims he is using actual causation analysis, while Landes and Posner use ex post actual causation analysis and claim they are using ex ante risk analysis.

This confusion is most evident in their discussion of Weeks $v$. $M c N u l t y,{ }^{69}$ a case in which the defendant, McNulty, failed to install the statutorily required fire escapes, but the court concluded that the victim had apparently panicked and would not have got to the fire escapes even if they had been installed. Under the traditional tort analysis, McNulty was negligent but is not liable for the victim's death since his negligence was not an actual cause of the death. This was the rationale given by the court: an actual causation rationale. But Landes and Posner argue:

[T] reason thus is to assume the conclusion. We want a ground of decision that will not depend explicitly on any notion of cause and we find it in the [Hand formula] analysis. . . . Evidence that the fire escapes would not have averted Weeks's death means, in the context of our model, that the probability of his death was independent of whether or not a violation occurred . . . and hence that due care with respect to [installing fire escapes] was zero. Stated differently, the defendant's failure to spend money on $z$ (fire escapes) was not a failure to use due care, in the economic view at least and in legal consequence, because the expected benefit of such expenditure would have been zero. ${ }^{70}$

The ex ante expected benefit of installing fire escapes was not zero. At the time of the defendant's decision not to install the fire escapes, which is the relevant time from the standpoint of evaluating the defendant's behavior either morally or economically, the failure to install the fire escapes obviously increased the risk of injury to the victim and every other guest in the defendant's hotel. It is only after the victim's death, when we look backward at everything that actually happened, that we know that the defendant's failure did not make a difference in this particular case. But the failure nevertheless was and still is inefficient behavior-it increased expected aggregate harm to all future guests, including the victim, by more than the cost of avoiding such expected harm (as the legislature de-

69101 Tenn. 495, 48 S.W. 809 (1898).

${ }^{70}$ Landes \& Posner, Causation, supra note 4, at 115-16. 
cided)-even though it did not contribute to (was not an actual cause of) the injury in this case. Landes and Posner are using an actual causation analysis, looking back at what actually happened, while claiming to be using the forward-looking risk analysis of the Hand formula.

They employ the same sleight of hand in their discussion of the doubtful causation cases, exemplified by the "man overboard" cases in which it cannot be determined whether the victim would have been saved if the defendant had provided the required rescue equipment on his vessel. They improperly measure the expected harm due to the negligent failure to provide the rescue equipment by an ex post analysis of the chance of rescue in the particular instance, given complete hindsight of everything that actually occurred. In one case, this ex post actual causation inquiry leads to a conclusion that there is only a small chance that the lack of equipment caused the victim's injury, so they declare that the optimal ex ante level of care was close to zero and the defendant is not liable. In the second case, there is a substantial chance that the lack of equipment caused the victim's death, so the defendant should have used more care and is liable. Contrary to their assertion, it is an ex post actual causation analysis that explains the difference in liability, rather than an analysis of the care due in the light of the ex ante expected harm (before anyone goes overboard), which is the same in both cases. ${ }^{71}$

If they consistently applied their method, they would be forced to find negligence liability in many cases in which the defendant's behavior was quite innocent but nevertheless caused an injury. For example, assume an automobile driver causes a serious accident despite careful driving. Under their method of using what actually occurred to calculate the required care, the "expected" cost of failing to exercise additional care was a 100 percent probability of a serious accident, which would almost always require much higher care than the driver exercised-for example, if nothing less would do, forgoing driving that day.

Landes and Posner have to limit their hindsight approach to avoid such a result in the Berry case, in which a motorman driving his trolley at an excessive speed was injured by a tree that coincidentally fell on the trolley as it was passing by the tree. ${ }^{72}$ If they evaluated the motorman's speeding in the light of everything that subsequently occurred, they would have to conclude that the speeding created a 100 percent probability that the motorman would be injured by the tree and that he therefore was con-

71 Id. at 120-22. They also revert to Posner's earlier, less formal mode of economic analysis: "[I]f the victim is fully compensated, too many persons who cannot swim will be induced to board ships." Id. at 121 n.28.

72 Berry v. Sugar Notch Borough, 191 Pa. 345, 43 A. 240 (1899). 
tributorily negligent. Instead, they limit their hindsight to the particular type of accident that actually occurred (tree falling on trolley), and they exclude the time and location of the accident. The speeding, then, did not increase the risk of the accident. In fact, it decreased the risk, since the train was a target for a shorter time due to the greater speed. So, they conclude, the motorman was not negligent. ${ }^{73}$ But given their approach it might well be argued that the motorman was negligent for not going even faster! In reality, using the proper ex ante (no hindsight) analysis of all the possible risks of speeding (for example, collision or derailment), the motorman was negligent, but his negligence (speeding) was not a proximate cause of the coincidental injury. ${ }^{74}$

In the brief mock war staged by Landes and Posner, it is clear that it is economic analysis, rather than causal analysis, that "has not proved illuminating. "75

\section{Conclusion}

The conceptual subtlety of the actual causation requirement misled the economic analysts into the belief or hope that the concept has no meaning at all and can therefore be ignored or manipulated. But their efforts to fit the requirement into their theories resemble the efforts of those trying to fit a square peg into a round hole. The requirement proved to have a more solid and definite form than they had previously realized. It requires that liability be conditioned on a backward-looking inquiry into individual responsibility for injury, and that individual responsibility be based on tortious behavior which contributed to the injury. Not surprisingly, the requirement also proved to be fundamentally inconsistent with their theories, which are not concerned with individuals or individual responsibility but rather with forward-looking assignment of liability to maximize aggregate wealth.

The failure of their efforts not only falsifies the positive theories of

${ }^{73}$ Landes \& Posner, Causation, supra note 4, at 119 \& n.21.

74 That is, although the excess speed was an actual cause of the injury, liability on the part of the motorman is denied for noncausal policy reasons, because of the coincidental character of the intervening events.

75 Landes \& Posner, Causation, supra note 4, at 134. Landes and Posner also restate Shavell's crushing liability and administrative cost arguments for restricting the scope of strict liability and negligence liability. Those arguments were elaborated and critiqued in the previous section and need not be repeated here. In addition to their weaknesses with the typical causation cases, they offer a conclusory economic account of the alternative causation cases and do not even discuss the duplicative and preemptive causation cases. See $i d$. at 124-25 \& n.35; William M. Landes \& Richard A. Posner, Joint and Multiple Tortfeasors: An Economic Analysis, 9 J. Legal Stud. 517, 540 (1980). 
Landes and Posner and their followers, but also casts substantial doubt on Calabresi's normative prescriptions, since the actual causation requirement has been the most enduring and pervasive element of tort liability over the centuries.

On the other hand, the demonstrated substance of the actual causation requirement-particularly given its focus on individual responsibility for injury-strongly supports the corrective justice conception of tort liability. Yet, as noted at the beginning of this article, the corrective justice conception remains incomplete in the absence of plausible comprehensive accounts of causation and rights. I address these problems elsewhere. ${ }^{76}$

76 See the articles by Wright, supra note 3. 